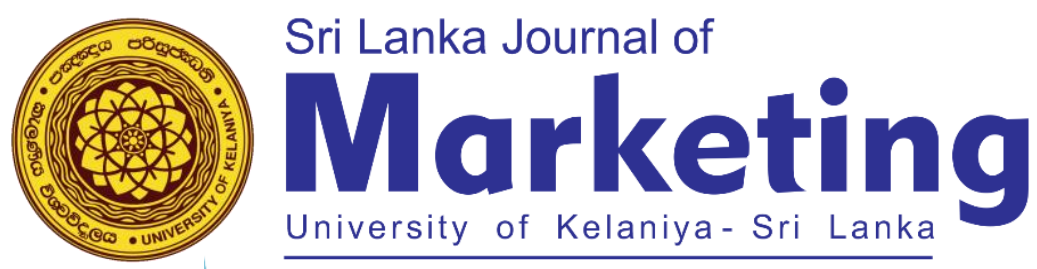

\title{
Tourism Amid Covid-19 Pandemic in Sri Lanka Way-Forwarding Strategies Through the Porters' Diamond Model
}

\author{
\begin{tabular}{|c|}
\hline Fernando, Imali $\mathbf{N}$. \\
Senior Lecturer, Uva Wellassa University, Sri Lanka \\
imalif@uwu.ac.lk
\end{tabular}
}

\begin{abstract}
Tourism has been emphasized as one of the main sources of foreign exchange for different economies in the world, whereas most of the developing countries recognized hospitality, Travel, and Tourism as an inspiring element for socio-economic prosperity. Within previous decades, tourism satisfaction or "choice for destinations" were gradually transformed towards different segments as a paradigm shift. The nature of tourism provides a pathway on socio-economic development, whereby entrepreneurship and venture creations, renewal of forgotten natural resources with new value addition, and diminishing the poverty line. Within this notion, COVID-19 Pandemic identified as a peripheral economic shock whereas distressing remarkably to the global economies contrarily by restricting human mobilization, entertainments, and events while negatively affecting the global economy. This paper adopts the Diamond model proposed by Porter by linking the vulnerability of the tourism industry in Sri Lanka during 1st-2nd waves of the pandemic. Research objectives were developed to identify the wayforwarding strategies on recovering the Tourism amid the COVID-19 pandemic, study sample had been derived by prioritizing the locked-down of the country by targeting key stakeholders, and data were qualitatively gathered. Within the light of the literature, each of the six facets has been identified as "Themes" and qualitatively discussed. As main findings, "situational forces" were emphasized as the most vibrant economic facet within the model, whereas the following main recommendations were proposed as way-forwarding strategies; (a) Safety, security, and political harmony of the country (b) Subsidies for tourism MSMEs and conducive environment for entrepreneurship. (c) Destination promotions / e-promotion platforms (d) Attracting foreign joint-ventures/ investments, (e) Healthy rivalry among the local firms and collective bargaining, (f) Prioritizing Spiritual, Health and wellness, Rural and Ayurveda tourism, (g) Popularizing Tea related Tourism through brand image of "Ceylon Tea"
\end{abstract}

Keywords: COVID-19 Pandemic, External Economic Shocks, Porters' Diamond Model, Tourism, Way-Forwarding Strategies 


\section{INTRODUCTION}

Travel and Tourism have been emphasized as the main source of foreign exchange as well as an emerging economic sector in the globe. In most developing countries, hospitality, Travel, and Tourism have been recognized as an inspiring element for socio-economic prosperity. Some scholars identified the sector as the number one ranked industry to the world economy herein, identified as a dynamic sector that vigorously assistances the global economic progression. According to World Travel and Tourism Council reports, tourism has contributed 10.3\% to the Global GDP in 2019 (WTTC, 2020). Further, Tourism has identified as one of the major economic sectors and due to the massive growth and development rate, the widespread volume of foreign exchange, and huge infrastructure development, all are contributing to the socio-economic development within different economies (Fernando, 2021). Within previous decades, the tourism satisfaction or "choice for destinations" were gradually changed towards different segments, as such relaxation, enjoy the nature, adventure and experience hunting. Herein the traditional tourism practices were slightly diminishing, by creating novel segments that are more focused on "feeling the destination and attributes". As scholars mentioned, the visitation process has converted into the areas of hunting for the experience, community engagements, and amusement-related experiences. These dissimilar revolutions have contributed to socio-economic development, high standard of resident livelihood, individual passion for life, and propensity to travel while forming novel tourism destinations around the world (Fernando, 2020). According to scholars, the sector correlates humans with relaxation, entertainment, adventure-seeking, inspiring the natural and cultural differences thus way forwarding human mobility and esteem needs (Fernando, 2016). Truly the sector is a vital economic imaginative for ability on destination prosperity whereas, contributing to enhancing the employments, foreign exchange producer, attraction for global investments and the main contributor on eradication of the poverty as highlighted by the World Travel and Tourism Council (Fernando and Long, 2012).

Tourism is a sector where the natural resource endowments of a country, such as salubrious climatic conditions, clean air, scenic locational beauty, landscape, bio-diversity are aligned with each other to provide "one tourist experience" to visitors. Scholars highlighted the true bond between these resources has led less-popular tourism segments to become identified and emerge, as such nature-based travels, Bio-diversity, Tea related tourism segments, mineral and gem-related tourism, and rural tourism (Pattiyagedara and Fernando, 2020). Within the latest decades, Special Interest Tourism (SIT) has emerged, while identifying the niche areas where could be targeted for a special segment of travelers. Among them, these segments were highlighted by (Fernando, 2012; Fernando et al, 2016); spiritual, medical, Sex, marine, Tea, Eco, Rural, Adventure, Agro, rural, community, and Culinary tourism. Most of those SIT highlighting the vital role-playing by the natural resources endowment of a destination, 
whereas even small destinations rather become a rich tourism hotspot. The structure of Tourism has been demonstrated with inter-related activities in Figure 1.

Figure 1: Structure of the Tourism

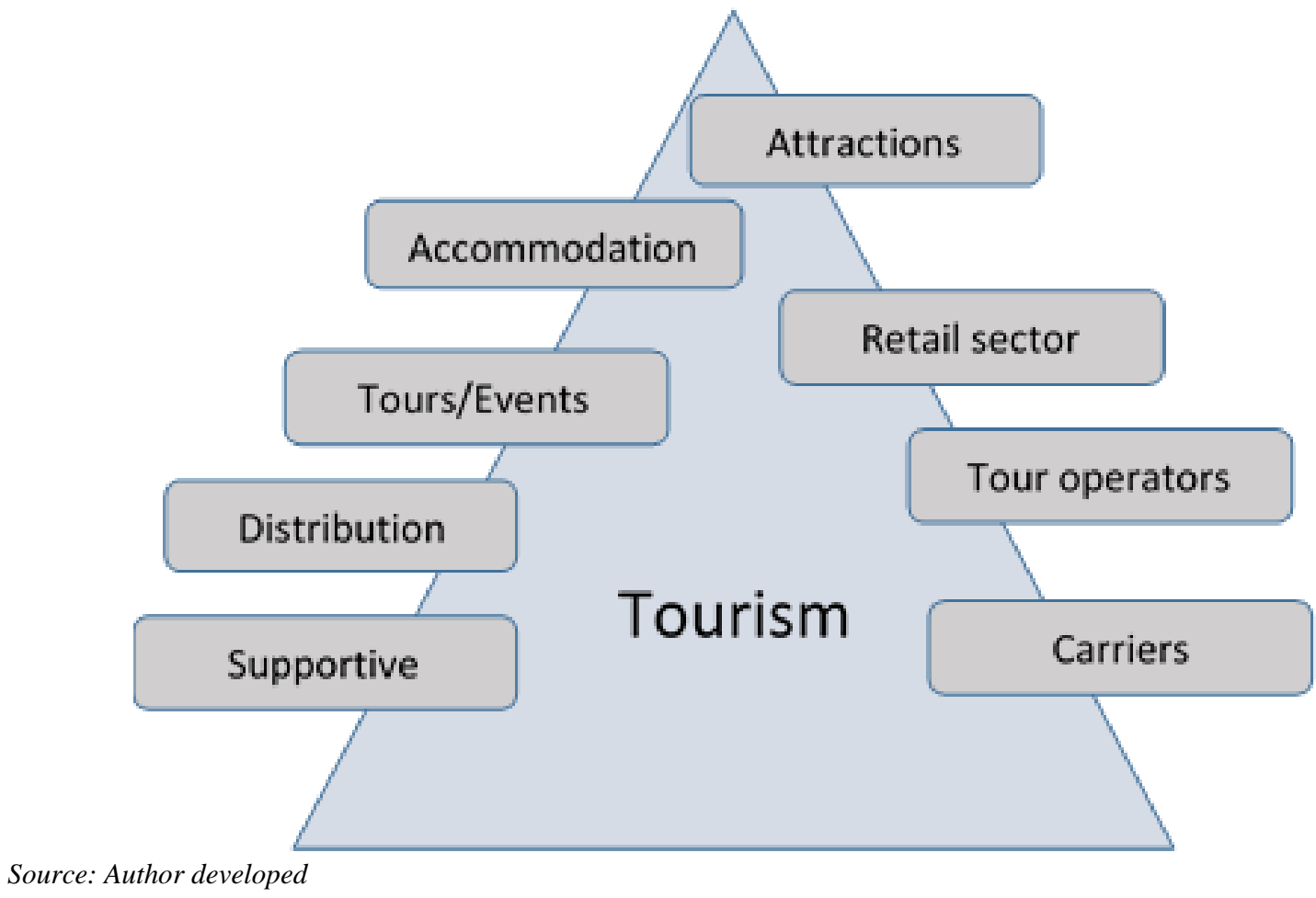

Further, the benefits of the sector will spread its wings towards the rural and regional developments, in a way of transportation, communication networks, house constructions, entrepreneurship, agricultural sector development, and value delivery networks. Further, these benefits finally move towards narrowing the income inequality between residents of a destination, while enhancing their livelihood. The nature of tourism provides a pathway on socio-economic development, whereby entrepreneurship and venture creations, renewal of forgotten natural resources with new value addition, and diminishing the poverty line. Further, tourism destination management is vital to be motivated by the theoretical reinforcements of the cutting-edge research, innovations, and supportive hand of the digital media (Fernando, 2020). Due to the expansion of transportation, communication, and ICT, more unpopular or hidden destinations emerged. Further, then travelers' perceptions of relaxation, leisure, and adventure have improved the tourism and internationalization process around the world (Cunha and Cunha, 2005). This "global visibility" has resulted in a huge influence on the local and regional socio-economic development, and some of the smaller destinations became the tourism hotspots. By disregarding the expansion level within each destination/economy or region, Tourism inherits the potentiality to create trade between each destination or cluster Bobirca (2007). Even though Tourism has created economic prosperity for many destinations, it also links with many destructive and sensitive issues within regional communities. Among them, the social violence, drugs, smuggling, destroying of cultural values, issues with environmentally protected areas in bio-diversity, sex-related issues, break-up the family structure, and cultural heritage could be highlighted as common for many destinations (Cunha and Cunha, 2005). 
Since from existence of the earth, and known as the "human generation", humans were exposed to numerous challenges, both natural such as earthquakes, floods, and artificially created such as war. Herein, the human was subjected to pathetic situations named as pandemics in different time-slots on earth (Fernández et al., 2020). Amongst, a disaster spreads around the world in the latter half of the year 2019 and first half of 2020, with massive damage to the life of human beings, named as. Corona Virus Disease-19 or COVID-19 (Qiu et al., 2020). First, the virus has been formed in Hubei province - China, later spread all around the globe, resulting in massive economic loss and life threats. Numerous public health procedures have been executed around the world as a preventive measure, such as social distance among people, ban the gathering and social events (Fong et al., 2020). Among all, the tourism sector immediately affected by this Pandemic, whereas a large number of countries and regions have imposed international travel restrictions, social events, gathering and functions, social distancing rules, health rules and restrictions on public transportation, air travel, passenger handling, and accommodations. Further, some countries strictly locked-downed the borders while resulting in a "sudden death" for travel and tourism. As stated by Kock et al, (2020), the pandemic will lead to a paradigm shift in travel behavior and decision-making, thereby disparagingly assess the core norms of the conventional concepts. As a result of the pandemic, a considerable number of famous travel destinations have imposed travel bans, closed down the tourist hotspots and Airline operations, shut the country borders, and introduce a new way of life "NEW NORMAL" with social distancing. These "NEW NORMAL" has created numerous challenges for the Tourism sector, and specially for the economies those are purely survive with the Tourist income.

\section{RESEARCH PROBLEM}

As in nature, Tourism is a sensitive industry and vulnerable to "external shocks" within the environment rather than any other industry. The nature of the "human touch" within the industry was the main reason behind this sensitivity. Further, as external shocks, any economic crisis or down-turns, social issues, environmental damages and rules, and political harmony could be highlighted. These cross-cutting nature could involve a probable socio-economic cost to the community and the consequences might be long-term for a destination. Further, to some extent, the industry associates with some negative social impacts also, whereby child phonography, nude-beach concepts, sex-related tourism, casino and gambling, drug additions among youth, illegal prostitution, and dejection of the traditional cultural values. Herein, the COVID-19 pandemic affected the whole industry overnight, which requires a longterm healing procedure. The imposing of travel restrictions and locked-downs ruined the nature of "travel" and spread fear among the people for "tourists". Even with different pandemics during history, the COVID-19 might be crowned as the best one, due to the massive global population, international mobilization, global transportation, and supply chain around the world. Further, the true nature of the high contagious of the virus spread fear among humans in every nook and corner. Accordingly, (Miller 
et al., 2005), the scholarly work focus on tourism clustering should see the novel avenue out from the classic Porter's cluster Diamond. Further, in addition (Wares et al., 2008; Ferreira et al., 2009), to the classical model, some scholars linked vital economic factors to the model, whereas, scholars stressed the limited number of scholarly work based on the model. Further, some scholars stated the lack of empirical studies on the practical use of the Diamond model (Cluster Diamond) proposed by Michael Porter (Fernando, 2012), whereas Enright et al., (2005), identify the Diamond model as the best model to identify the competitiveness of economies, specially the national competitiveness.

The author identifies the research question by linking the vulnerability of the tourism industry in Sri Lanka during the 1st-2nd wave of COVID-19. As the study framework, the paper demonstrates the "Diamond model" by linking the main stakeholders of the sector.

The main research question has been identified in this context as;

What are the stakeholders' perceptions on recovering Tourism in Sri Lanka amid the COVID-19 pandemic?

The study objective is clearly defined by the author, as to qualitatively assess the perceptions of stakeholders for "future perspective" of Tourism after the COVID-19 pandemic.

Research objectives were formulated as;

- Identify the stakeholders' perceptions on recovering Tourism in Sri Lanka

- Proposing a set of strategies to recover Tourism in "NEW NORMAL"

The paper adopts the economic variables /facets of the Diamond model to achieve the research objectives. The study framework lays within the 1st and 2nd waves of the COVID-19 pandemic in Sri Lanka.

\section{REVIEW OF LITERATURE}

Tourism is a widespread phenomenon and accounted as one of the main economic sectors among the world economy, where the main aims of relaxation, leisure, and pleasure have embedded. The nature of this tourism and hospitality sector is diverse than most of the other service industries, where the customer needs to start the "visitation" process (Miller and Gibson 2005; Kvist et al.,2006). The opening up of the national economies in the 1980s results in human mobility, globalization, and travel tourism around the globe. Further, Cunha and Cunha (2005) stated, these factors were the hidden force behind being ranked as one of the significant global sectors, rather than second only to the Finance sector. The rivalry is intensive among this industry, whereas a large number of developing countries and smaller Island destinations are emerging within. Hence the tourism destinations should ensure on following factors to be highlighted than the rivals; (a) tourist satisfaction (b) profitability and growth of industries 
(c) minimize economic leakages (d) resident's high standards of living and (e) environmental sustainability via sustainable tourism concept (Fernando 2015). As scholars highlighted (Inman et al.,2002), countries with less natural resources have emerged their strategy to be more innovative.

Thus these innovative processes and products could bring up the level of those less-privileged destinations to prosperity. Competitive skills, as a nation's prosperity, depends on the level of productivity and competitiveness of business and industries. The nature of these vital forces has been depicting in figure 2 .

Figure 2: Offering the competitive advantage

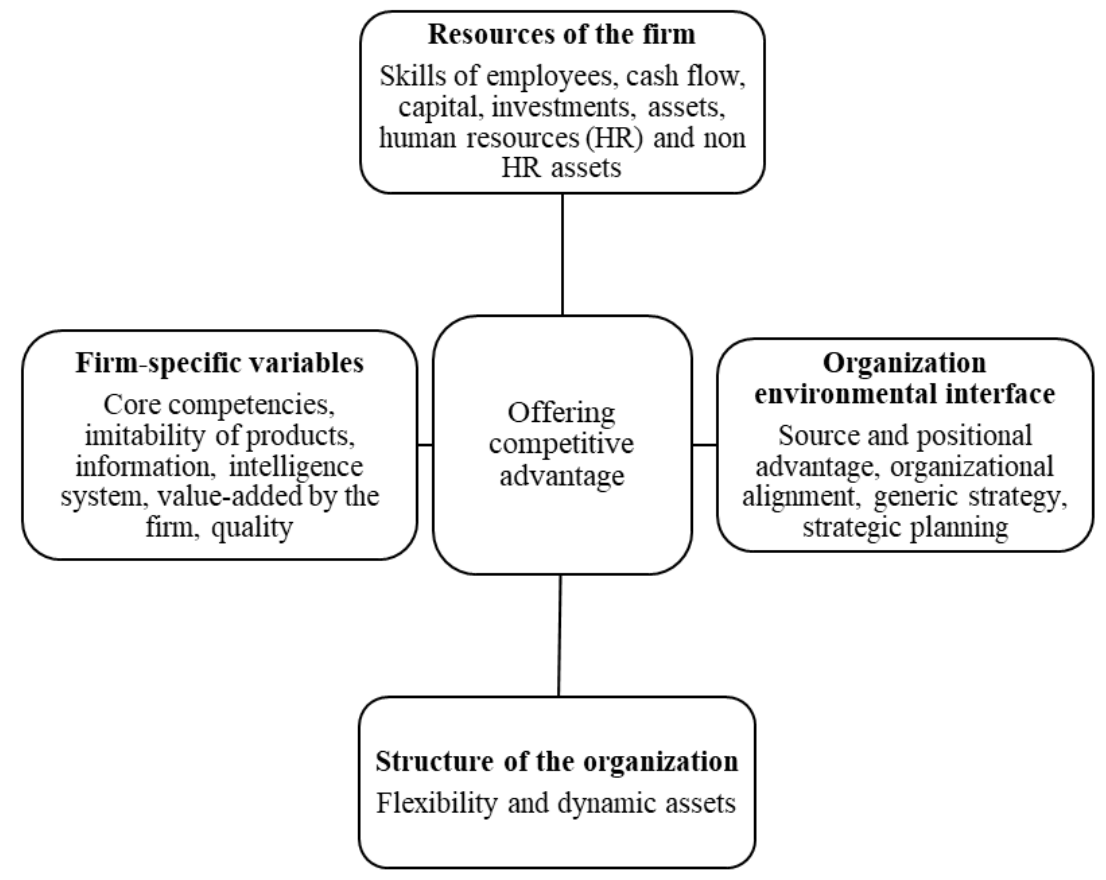

Source: developed through Literature review

Scholars highlighted the vital role play by the continuous innovations on products and services (Kim and Dwyer, 2003) and these questions are vital; "how significant the natural resources equated with the destination image? How imperative the price competitiveness and the management"? On the contrary, the locational advantage of a destination is vital to rivalry. Tourism is naturally covered with linkages in diverse directions to provide a tourism experience by the visitation process as the final product. Indeed, there are countless stakeholders involved, directly and indirectly, and each participant strives to enhance the "perceived satisfaction" of the tourist. Hence this will enhance the image of the country as well creating a re-visit intention of the tourist. Policies and plans, organizational structures, and marketing strategies drive destinations more prosperity Crouch and Ritchie (1995), whereas the hidden key to become a top tourist destination. As a result, most countries are welcoming the tourists but undertaking little to intervene within the visitation process. That will intervene with the external 
environmental shocks such as civil war, Bomb attacks, natural disasters and virus attacks like COVID19.

\subsection{Comparative Advantage}

Destinations factor endowment in both, naturally occurring and created resources closer with primary tourism supply as forms of natural, cultural, and social attractions, (Bobirca et al., 2006). Further, it elaborated as broad categories of resource endowments as HR, physical resources, knowledge resources, capital resources, infrastructure, historical and cultural resources in a particular tourism destination. Herein the scholars, (Crouch and Richie, 1999, Bobirca et al., 2006) highlighted the importance of natural resources as an important source on the tourism comparative advantage, whereas Kulcsar (2009) pointed out this as the clean natural environment, quietness, scenic beauty, topography, fresh air, local people involvement within the hospitality sector, gastronomy which have collaborated with the rural lifestyle and preserved traditions and heritage.

\subsection{Competitive Advantage}

Focuses on the strategies which transform the comparative advantage towards global competitiveness. According to scholars (Bobirca et al., 2006) this link with the secondary tourism supply whereas how effectively a destination can use the resources, especially comparative advantage. Therefore, the competitive advantage of a destination is linked with the infrastructure, skills of the workforce, management competencies, government policies, and regulations (Kulcsar, 2009) some scholars highlighted the importance of Destination Management Organizations (DMO) as a way to effective management of the comparative advantage or resource endowment. This overwhelms to encourage the entrepreneurial sphere on thinking and working together towards complex supply packages, build destination image and way forwarding promoting activities. Herein, the comparative advantage relates to primary tourism supply whereas the competitive advantage is linked with the secondary tourism supply.

\subsection{Conceptual Model: The Diamond Model}

The diamond model is the articulated actions of four economic variables or facets that are shaping the national competitive advantage. The model proposed by Porter in 1990, whereas linking the economic variables. The diamond model consists of Factor conditions, Strategy business structure and rivalry, Demand conditions Related to and supporting industries, sub-facets; government, and Chance / Situational forces.

The comparative and competitive advantage of tourism is a broad concept, as it has defined broadly by scholars (Bobirca et al., 2006; Fernando and Long, 2012), are playing a vital role in international 
tourism. Mainly for comparative advantage related to inherited resource endowments such as scenic beauty, flora, and fauna, biodiversity, climatic conditions, mountains, and rivers whereas, competitive advantage refers to destination management and how far a destination can face the rivalry. Hence the competitive advantage aligns with the quality of destination management, HR skills, and policies of government-imposed. Cracolici and Nijkamp (2006) mention the comparative and competitive advantage of tourism with two terms; (1) resource endowment as the comparative advantage and (2) resource deployment as the competitive advantage. Hence the resource endowment refers to human, physical, knowledge, capital resources as infrastructure/tourism superstructure, cultural/historical and heritage resources, and the resource deployment as audit and inventory, development, growth aspects, maintenance within the industry, efficiency, and effectiveness. Both quantitative aspects like the number of visitors to a tourism destination, market share, direct -indirect employment, tourism receipts, and qualitative measured variables as cultural heritage, topography, marine resources, and golden beaches, mountains and waterways, scenic environment all are linking to provide the "tourism experience" for the tourist (Kulcsar, 2009). Tourism is in a "paradigm shift" where the comparative advantages become less important than the competitive advantage within destinations (Iordache et al., 2010). This would result in traditional tourism destinations with a high comparative advantage will be less popular, while opening up new Travel destinations. This paradigm shift has created completely new tourism destinations to become popular regardless of the "resources endowment they have" by resulting in economic prosperity.

The Diamond model depicts the articulated actions of four determinants or economic variables as;

a) Factor conditions: allocation of country's factor of production

b) Strategy business structure and rivalry: conditions that regulate the creation, organization and management and the domestic level rivalry

c) Demand conditions: domestic demand

d) Related and supporting industries: the presence of the supporting and related industries

Other than main economic variables, as sub variables following two variables were introduced to complete the picture of a Diamond

f) Actions on government /Government Institutes

g) Chance / situations forces

The diamond model by Porter (1990), is supposed to represent how an economy, firm, or cluster can create a competitive advantage on an economy and specially the national Competitiveness. The Diamond model has been depicted in figure 3 . 
Figure 3: Diamond model

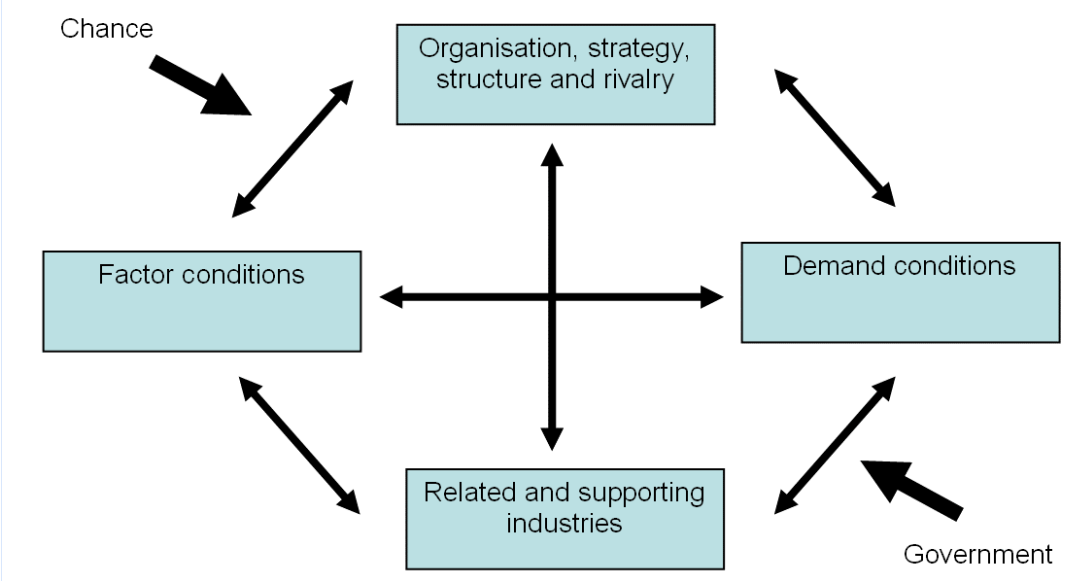

Source: Adopted from Porter (1990)

\section{RESEARCH METHOD}

The paper mainly focuses to identify the stakeholders' perceptions on recovering Tourism in Sri Lanka amid the COVID-19 pandemic. Hence the research method is aligning with the qualitative assessment with the stakeholder perceptions on the "future perspective" of Tourism after the COVID-19 pandemic. Further, the paper will propose a set of strategies to recover Tourism in "NEW NORMAL" amid the COVID-19 pandemic. The study population consisted of all tourism sector supply-side stakeholders in the local context. Since the country in the second wave of COVID-19, the study sample was selected from the locked-down areas of the country. As a vulnerable industry, the sector was devastated and the locked-down situation created the tourism stakeholders as "zero-income earners", whereas a huge amount of indirect employments also stagnated. The sample consisted of 50 tourism supply-side stakeholders and the structured interview sessions were conducted with a structured interview guide. The interview guide developed based on each of the economic variables of the Diamond model. Interview sessions were conducted basically via online methods and the data collection was accompanied in March - November 2020 (within the 1st and 2nd waves). The sample was distributed by covering the major tourist destinations in the Western province since the province was locked down during the 2 nd wave due to a huge number of positive cases.

Figure 4 depicts the sample distribution, whereas the respondents were scattered among all three districts of the Western Province. 
Figure 4: Sample selection

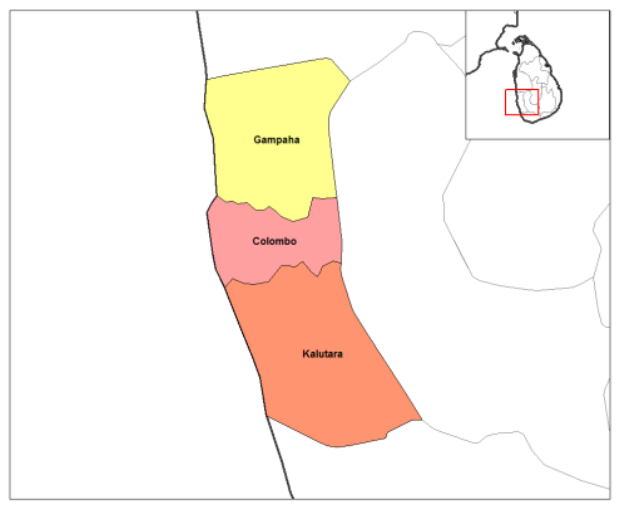

The research is qualitative in nature, whereas the snowball sampling method was adopted to meaningfully locate the key supply-side stakeholders in diverse tourism associations. Due to the social distancing rules imposed by the Government, the global Travel and Tourism sector was highly affected due to the nature of the sensitivity. Since Tourism is one of the key industries within the Sri Lankan economy, the situation further worsened without any second thought. Specially the accommodation sector was highly affected due to the strict travel bans, closed down of the Airport, ban all tourist arrivals and cancelations of the events. This further worsened due to the cancellations of domestic gatherings, functions, and social events as wedding ceremonies. Therefore, the key stakeholder's perceptions via qualitative analysis that has been focused on the Porters' Diamond model were identified. Since the study method is qualitative, the author adopts the "thematic analysis method", where the identified themes are in line with the Conceptual model- Diamond model. The economic variable and behavior of the variables within the pandemic will provide fruitful insights to identify the "way-forwarding strategies" for the Tourism industry amid the Pandemic.

\section{RESULTS AND DISCUSSIONS}

In the light of the scholarly works which were focused on the Diamond model, each of the economic variables or the facets of the model has been qualitatively assessed to identify the way-forwarding strategies to the sector. The author adopts these six parental themes which are linked with the conceptual model, whereas;

Theme $1 \rightarrow$ Factor conditions

Theme $2 \rightarrow$ Demand conditions

Theme $3 \rightarrow$ Business strategy, structure and rivalry

Theme $4 \rightarrow$ Related and Supporting Industries

Theme $5 \rightarrow$ Role of the government

Theme $6 \rightarrow$ Chance /Situational Forces 


\subsection{Theme 1: Factor Conditions}

Conventionally factor conditions refer to the raw materials and traditional infrastructure availability. When it applies to the Tourism sector, the factor conditions referred to the product, service, and experience combinations that make up the industry. Scholars identify the factor conditions as the scenic beauty, climatic conditions, salubrious environment and topography, natural attractions, cultural assets and heritage, outstanding cuisines enriched with heritage, cruise ships and airlines, and the convenient air and highway access (Miller and Gibson, 2005, Fernando and Long, 2012). Further, the multi expertise both in human resources (HR) as such, fluent in languages and different cultures, health and fitness personnel trainers, fine cuisines and liquor, strategic foreseeability, language skills, and hospitability of the employees also identified as factor conditions. When compared to the tourism sector, natural and created resource endowment might lead for the "specialization", whereas these specialized factors are often not inherited, but increasingly man-made, as created from gaining skills from such education activity or system, high-tech breakthrough, or such specialized infrastructure growth (Fernando, 2015). Hence, it could be summarized as (a) natural resources of the country (b) cultural and heritage resource endowments of the country, (c) skilled or trained HR, (d) infrastructure development on natural and cultural resources, (e) capital market structure conducive to the long-run investments and (f) involvement of the residents.

Accordingly, with the Theme 1, following were identified by the respondents;

As a tourism destination, Sri Lanka is rich with natural resource endowments which include scenic beauty, topography, tropical climate, year-round sunlight, locational advantage, surrounded by Sea, rich culture, and heritage. Further, other than natural resources endowments, the destination is rich with general infrastructure as highways, new airports, local transportation, skilled and trained HR who is fluent with main foreign languages, high literacy rates, and use of English language by the common public. Hence as recovering strategies amidst the COVID-19 Pandemic, these three strategies were highlighted referring to the Diamond model within the local context;

i. Focusing on Special Interest Tourism (SIT) segments of Spiritual tourism, Health and wellness tourism, Rural tourism, Ayurveda related segments, and nature-based travels segments as Tea tourism

ii. Development of the Human Resources (HR) skills to acquire the required skills in "New Normal"

iii. Implementation of the knowledge transfer Institutions, IT, and communication infrastructure 


\subsection{Theme 2: Demand Conditions}

Demand conditions are further highlighted by the sophisticated demanding patterns, domestic travelers' demand patterns, and novel "shifts" within the demand. Some scholars emphasized (Miller and Gibson, 2005) most of the developing countries got an insignificant local base of sophisticated and demanding tourists, which resulted to let alone the upper-tier tourism development only. Absence of the sophisticated domestic demand might worse the tourism sector specially from a sudden shock within the external environment, as a terrorist attack, civil war, or a pandemic. According to Lin and Juan (2010), the existence of large-growing market segments ultimately produces a favorable demand condition within a country, whereas the niche-market segments would create a huge value. As a result, most of the small firms can get a competitive advantage from those niche markets. Herein domestic demand is vital to enhance the "industry-level innovations" and to reduce the communication channel length (Nordin,2003; Fernando,2015).

In a summary, the respondents agreed on the structure and size of the market, tastes of the travelers, desires of tourists with visitation process will be causative as main demand factors with the pandemic. Further, since the sector has taken a smaller attempt to identify the domestic demand and domestic tourism, this "New Normal" could be the best era to cater towards the domestic market. Further, investing more in SIT's such as spiritual tourism, health, and wellness tourism could act as a breeding ground for innovations with the emerging domestic demand. In this context, domestic travel preferences should be monitored by the industry.

Hence as recovering strategies amidst the Pandemic, these four strategies were highlighted referring to the Diamond model which is a link with eco-friendly, activity-oriented, and nature-based exposure;

i. $\quad$ Encourage domestic tourism by linking nature-based and eco-friendly travels

ii. Propagating the spiritual, health and wellness, Ayurveda related among the domestic market

iii. Popularizing water-related tourism activities as such; coral reef diving, Whale and Dolphin watching, surfing, Snorkeling among domestic market

iv. Destination branding

\subsection{Theme 3: Business Strategy, Structure and Rivalry}

This facet of the Diamond model is focused on the structure of the industries, strategy on the various firms with their interconnectivity and rivalry. This further emphasized by different scholars, whereas the existence of rich natural resource endowments no longer makes it more "competitive" whereas the "competitive strategy" might do (Fernando, 2015). The Diamond model focuses more on this facet, whereas the structure of the industries, their interconnecting strategies, and healthy rivalry would be the most important aspects. 
The core of the industry will eventually lead to the establishments of different sub-sectors whereas the hotels, resorts, theme parks, animal sanctuaries, and entertainment attractions, and so on those are leading towards the socio-economic development of a country. Herein the structure of the firms, interconnecting strategies, and rivalry focus on business strategies, strategic alliances, attitudes of the policymakers, and entrepreneurial predilection (Lin and Juan, 2010) will way forward the industry. Respondents all agree with the vital role play by the industry structure, organization- management, and context for domestic rivalry, healthy competition between different firms, entrepreneurial predilection, and innovative business practice. Therefore, these three strategies were highlighted by the respondents which have a link with the

Diamond model;

i. Healthy rivalry among the local firms and collective bargaining

ii. Focus on specialty markets and niche markets as a strategy

iii. Prioritizing the tourism Micro, Small and Medium Sector Enterprises (MSME)

\subsection{Theme 4: Related and Supporting Industries}

This facet of the model is emphasizing towards the industrial linkages among the related and supporting industries. According to the scholars (Miller and Gibson, 2005), these goals might lead to the growth of any industry as such; a) lengthening and strengthening the support for the core industry and b) reducing the leakages of the economy within the region. Hence the supply chain efficiency and strengthening the value-creation network among different industries (related -supporting) will prosper the industry growth. Some scholars stressed (Fernando, 2021) the tourism leakages within the valuedelivery network are substantially high in most of the developing economies. Hence, the related and supporting industry economic leakages would be maintained in a minimum position to enhance the economic value addition. All the respondents agree with the support provided by the related and supporting industries for Tourism in Sri Lanka. Further, the lack of related and supporting industries might hinder the growth of Tourism whereas the support of the related -supporting industries should be promoted. Herein following could be identified, shopping malls, natural resources, and venture creation, institutions as medical centers, local entrepreneurship development, IT, communication, and security.

As a summary, two way-forwarding strategies were highlighted by the respondents to be resilient in "New Normal";

i. conducive environment for the related-supporting industries in Sri Lanka whereas to diminish the economic leakages

ii. diversification of the industrial sector with novel venture creation 


\subsection{Theme 5: Role of The Government}

Government can enhance or hinder the competitiveness of any industry with diverse roles within the system. Hence, industrial infrastructure growth, attracting new foreign investments, way forwarding foreign joint-ventures or acquisitions, safety, and a peaceful political environment within the country are vital (Fernando, 2021). The potentiality of the government to foster the equity among the benefitcost and mitigating with the industrial -base with resource endowments will assure the economic equality (Miller and Gibson, 2005).

In summary, the respondents highlighted the government as a sole-policy developer for an economy as well the tourism industry, whereas to accelerate the prosperity. Within the face of "New Normal", almost all of the policies regulations should be again re-addressed and novel regulations would be imposed on local industrial development, protecting the infant industries, venture creation, subsidies for tourism MSMEs, and destination image building. Herein, the following strategies were identified by the respondents as to be resilient within the pandemic;

i. Safety, security, and political harmony of The country

ii. Impose subsidies for tourism MSME's

iii. Destination promotions collaborating with the e-promotion platforms

iv. Attracting more foreign joint-ventures and investments to the country

\subsection{Theme 6: Situational Forces or Chance}

As the last sub-economic facet, the situational forces are linked with the external economic shocks, threats from the macro environment, political changes, novel market trends and patterns, disasters, and pandemics where the destination does not have any controlling power. Due to the nature of the dynamic environment, the 'chance or situational forces' are the places where the industry would link more innovations or "out-of-box strategies" (Fernando, 2021).

Within the sample, all the respondents highlight this facet as the most influential facet, due to the nature of the variable. Further, as a vulnerable industry to the "external shocks" as a disaster or a pandemic like COVID-19, Tourism would come out with a "second plan" or "plan B" on execution. Therefore, following way-forwarding strategies were prioritized by the respondents and align to the Diamond model;

i. Innovative experience packages as novelties catering nature-based segments

ii. Health and wellness tourism and e-promotions among the international market

iii. Linking Ayurvedic treatments and herbal medicines

iv. Popularizing Tea related Tourism through brand image of "Ceylon Tea" 
As a conclusion, almost all respondents highly expressed the stakeholders' vulnerability to the pandemic as an external shock as the most vital facet of the Diamond model. Further, Pandemic inspire the tourism industry as an external shock, whereas "out-of-box" strategies and innovations would be proposed by the industry. Further, the pandemic has been highlighted to responsible for the downturn of the market than other forces of the model. Hence, these mentioned 6 themes with each of the identified way-forwarding strategies are proposed to the industry within the "New Normal"

\section{CONCLUSIONS AND RECOMMENDATIONS}

Hospitality, Travel, and Tourism are considered as one of the main economic sectors and a multicomplex system, which includes food and accommodation, entertainment, pleasure and leisure, events, spiritual and community involvements. Tourism is a vital economic sector that is combined with both comparative advantage and competitive advantage, where each destination enriched with a unique set of endowments and strategies to enlighten. Within this notion, the COVID-19 Pandemic considered as an external environmental shock whereas affecting highly for the world economy by destructing human mobilizations, social functions and entertainment, leisure and pleasure of the society, and foreign income earnings. Further, the obstacles might be worse due to the vulnerability of the sector and the dependency of most of the developing economies around the tourism industry.

This paper adopts the Porters' Diamond model to the Tourism in Sri Lanka by specially focusing on the key stakeholders in Locked-down areas, to identify the way-forwarding strategies amid the Pandemic. Research literature identifies a lack of scholarly work which are related to the empirical analysis on the practical use of the Diamond model proposed by Michael Porter (Miller et al., 2005 and Fernando, 2012). Within the developing countries (Wares et al., 2008; Ferreira et al., 2009), there are a limited number of studies catered to the Diamond model. Hence this paper highlights an attempt to identify "hidden perceptions" among the key industrialist during the 1st and 2nd waves of the COVID-19 pandemic. As the methodology, the study sample had been derived by prioritizing the locked-down areas due to COVID-19 in the Western Province, Sri Lanka by targeting 50 key stakeholders. Structured interview sessions were conducted via online methods and the snowball sampling method has been adopted to meaningfully locate the key stakeholders in diverse tourism involvements. Within the light of the previous scholarly works, each of the facets of the Diamond model has been qualitatively discussed by designating as "themes", and focus on the main objective to identify the way-forwarding strategies within the sector amid the Pandemic. Accordingly, situational forces were identified as the most vital facet of the Diamond model and further highlighted the external environmental shocks that might shape the future sustainability of the industry. Most respondents highlight the importance of the destination brand, image for "Ceylon Tea" and tendency towards Health and wellness tourism might be the future prospects of the Tourism in Sri Lanka. 
Herein, following key recommendations have been proposed to the Tourism;

- Safety, security, and political harmony of the country

- Impose subsidies for tourism MSME's and a conducive environment for entrepreneurship

- Destination promotions collaborating with the

- e-promotion platforms

- Attracting more foreign joint-ventures and investments to the country

- Healthy rivalry among the local firms and collective bargaining

- Focusing on Special Interest Tourism (SIT) segments of Spiritual tourism, Health and wellness tourism, Rural tourism, Ayurveda related segments, and nature-based travels segments as Tea tourism

- Development of the Human Resources (HR) skills to acquire the required skills in

- "New Normal"

- Popularizing Tea related Tourism through the brand image of "Ceylon Tea"

Paper provides research directions for the future scholars, as such empirical testing of each facet of the Diamond model by approaching country-wide sample. Further, this model could be tested in a comparative approach whereas different regions, segments, or even destinations could be targeted. Hence these findings will be a guiding light for the policy makers since these are specially catering to the impact of the COVID-19 on Tourism in Sri Lanka. 


\section{REFERENCES}

Annual Statistical Report of Sri Lanka Tourism, Sri Lanka Tourism Development Authority, 2018 and 2019

Armenski, T., D. O. Gomezelj, B. Djurdjev, L. Deri and D. Aleksandra, (2011). Destination Competitiveness: A challenging Process for Serbia, Journal of studies and Research in Human Geography (1), 19-33

Bobirca A. (2007). Assessing the International Competitiveness of Tourism Services Trade, Romanian Economic Journal, X (23),29-43

Bobirca A. and Cristureanu C., (2006). Competitiveness Assessment and growth opportunities of the Romanian tourism sector, The Romanian Economic Journal, IX (21)

Crouch G.I. and Ritchie J.R., (1995). Destination competitiveness and the role of the tourism enterprise, Working paper, WP 95-19

Crouch G.I. and Ritchie J.R., (1999). Tourism, Competitiveness and Societal Prosperity, Journal of Business Research, 44 (3),137-152

Cunha S.K and J. C. Cunha, (2005). Tourism Cluster Competitiveness and Sustainability: Proposal for a Systematic Model to Measure the Impact of Tourism on Local Development, Brazilian Administrative Review, 2 (2), 47-62

Dwyer L. and C. Kim, (2003), Destination Competitiveness: A model and Determinants, Current Issues in Tourism, 2003

Enright M.J. and J. Newton, (2005). Determinants of Tourism destination competitiveness in Asia Pacific: Comprehensiveness, Journal of Travel Research, 43, 339-350

Fernando Imali N., (2015)., "What competitive strategies way forward the regional competitiveness? A comparative Economic approach to Sri Lankan Tourism, International Journal of Business and Management, $10(4), 178$

Fernando Imali N., (2020)., "Tourism competitiveness by shift-share analysis to way-forward Destination Management: A case study for Sri Lanka”, Journal of Tourism and Services, 11 (21), 88-102

Fernando Imali N., Wei Long, (2012). "New conceptual model on cluster competitiveness: A new paradigm for Tourism?", International Journal of Business and Management, Canadian Center of Science and Education, $7(9)$

Fernando Imali N., (2012). "Towards an Integrated Conceptual Model on Tourism Competitiveness: Does Clustering Way Forward?” International Journal of Research in Commerce and Management, II (XI)

Fernando I (2021), Book chapter "Assessing the Competitiveness of Sri Lanka's Tourism in the COVID Period by Porter's Diamond Model”, Handbook of Research on Strategies and Interventions to Mitigate COVID-19 Impact on SMEs, IGI Global publishing, USA, ISBN: 9781799874362, DOI: 10.4018/978-1-7998-7436-2

Ferreira J and Estevao C., (2009). Regional Competitiveness of Tourism Cluster; A conceptual model proposal, MPRA paper no.14853,25, 17-51

Inman C, Segura G., Moreno J. and Prado A., (2002). Tourism in El Salvador -The competitiveness Challenge, Working paper, CEN 621

Iordache C., Ciochina I. and Asandei M., (2010). Clusters-Tourism activity increase competitiveness support, Theoretical and Applied Economics, XVII (5), 99-112 
Kim C. and L. Dwyer, (2003). Destination Competitiveness and Bilateral Tourism flows between Australia and Korea, The Journal of Tourism Studies, 14 (2), 55-67

Kock F, Astrid N., Josiassen A., Assaf G. and M. Tsionas (2020), Understanding the COVID-19 tourist psyche: The Evolutionary Tourism Paradigm, Elsevier Public Health Emergency Collection, November 2020;85

Kulcsar, N. (2009), Rural tourism in Hungary: The key of Competitiveness, Proceedings of FIKUSZ 09, Symposium for Young Researchers, 121-127

Kvist A.K.J. and B. Klefsjo, (2006). Which Service Quality Dimensions are Important in Inbound Tourism?, Managing Service Quality, 1 (5), 520-537

Lin C.T, and P.J. Juan,(2010).Measuring location selection factors for international resort parks, Qualitative and Quantitative, 44,1257-1270

Miller M.M. and Gibson L.J. (2005). Cluster Based Development in the Tourism Industry; Putting Practice into Theory, Applied Research in Economic Development, 47-63

Nordin S. (2003). Tourism Clustering and Innovation- path to Economic Growth and Development, European Tourism Research Institute, U 2003, 14

Pattiyagedara S. and Fernando P.I.N, (2020), Rural Tourism Niche-market as a development strategy on rural community: Refernce to Hiriwadunna Village Track, Meemure and Heeloya Knuckles Valley Tourism Village, Sri Lanka, Sri Lanka Journal of Management Studies, 2(1), 87-103

Porter M.E.,(2000), Location, competition and Economic development: Local Clusters In A Global Economy, Economic Development Quarterly, 14 (1),15-34

Porter, M.E. (1990), The Competitive Advantage of Nations, The Free Press

Porter, M.E. (2001). Clusters of Innovation: Regional foundations of US Competitiveness, report for Monitor group, council on Competitiveness, USA

Sri Lanka Annual Statistical Report (2019), Research and International relations division, Sri Lanka tourism Development Authority

UNWTO - United Nations World Tourism Organization Annual Report ,2019

Walsh, M., P. Lynch and D. Harrington (2003). A proposed model of firm-level Innovativeness: the small tourism firm, The national development plan of Ireland 2007-2013, Tourism policy Review

Wares A.C. and Hadley S.J. (2008). The Cluster Approach to Economic Development, Technical Brief No.7

Yuksel A. and Yuksel F.,(2000). The quest for quality and Competitiveness: A case of Turkish Tourism, Sheffield Hallam University 